\title{
BLUE RUBBER BLEB NEVUS SYNDROME: CASE REPORT
}

\author{
Magaly Gemio Teixeira, Marcos Vinicius Perini, Carlos Frederico S. Marques, \\ Angelita Habr-Gama, Desidério Kiss and Joaquim J. Gama-Rodrigues
}

TEIXEIRA MG et al. - Blue rubber bleb nevus syndrome: case report. Rev. Hosp. Clín. Fac. Med. S. Paulo 58(2):109-112, 2003.

The case of a patient with blue rubber bleb nevus syndrome who is infected by acquired immunodeficiency syndrome virus due to multiple blood transfusions is presented. This case shows that although it is a rare systemic disorder, blue rubber bleb nevus syndrome has to be considered in the differential diagnosis of chronic anemia or gastrointestinal bleeding. Patients should be investigated by endoscopy, which is the most reliable method for detecting these lesions. The patient underwent gastroscopy and enteroscopy via enterotomy with identification of all lesions. Minimal resection of the larger lesions and string-purse suture of the smaller ones involving all the layers of the intestine were performed. The string-purse suture of the lesions detected by enteroscopy proved to be an effective technique for handling these lesions, avoiding extensive intestinal resection and stopping the bleeding. Effective management of these patients demands aggressive treatment and should be initiated as soon as possible to avoid risks involved in blood transfusions, as occurred in this case.

DESCRIPTORS: Blue rubber bleb nevus syndrome. Hemorrhage. Surgery.

Blue rubber bleb nevus syndrome is an uncommon systemic disorder characterized by cutaneous and gastrointestinal hemangiomas with an approximate incidence of $1: 14,000^{1,2}$. It was first described by Bean ${ }^{3}$ in 1958 , who named the syndrome because of the bluish color of the nevi and their rubbery consistency at palpation. The typical finding in this disease is venous malformations, which are present at birth or may appear in childhood and increase in size and number with age. Early diagnosis and management are important because of the potential for serious or fatal bleeding ${ }^{4}$. We report a case of late successful treatment of a patient that due to several blood infusions was infected with acquired immunodeficiency syndrome virus (AIDS).

\section{CASE REPORT}

A 19-year-old woman was admitted with a 10-year history of sporadic episodes of melena and fatigue. She had been admitted several times at the emergency service because of anemia, receiving blood transfusions, with temporary improvement of her condition. She underwent an operation to excise a head tumor at the age of 3 . The admission blood cell count revealed $\mathrm{Hb}=4.9$ and $\mathrm{Ht}=16 \%$ and positive tests for AIDS. Other labora-

From the Department of Gastroenterology, Division of Gastrosurgery and Coloproctology, Hospital das Clínicas, Faculty of Medicine, University of São Paulo. Received for publication on May 13, 2002. tory tests were normal. The patient underwent the following examinations:

- Upper gastrointestinal endoscopy revealing 3 wine-colored lesions of about 4 to $6 \mathrm{~mm}$ in the stomach and 1 in the duodenum;

- Colonoscopy revealing polypoid lesions in rectum, sigmoid, and transverse colon;

- Enteroscopy with visualization of $20 \mathrm{~cm}$ from the Treitz angle showing a bluish lesion;

- Abdominal CT scans revealing soft tissue masses in the gluteus region;

- Selective angiography revealing vascular anomalies in the second and third portion of the duodenum. The patient underwent surgery. The gastric and duodenal lesions were identified by intraoperative endoscopy, resected, and sutured with sta- 
ples through gastrostomy and duodenectomy. We performed an enterotomy between the angle of Treitz and the ileocecal valve. An enteroscopy was performed through this opening proximally and distally. Several bluish vascular lesions were detected (Fig. 1). Each one was treated with a pursestring suture involving all the intestinal layers (Fig. 2). Only one was resected and sent for histopathological examination (Fig. 3). The study and treatment were completed with a colonoscopy that detected 3 lesions; 1 was resected, and 2 were treated with a purse-string suture. The postoperative recovery was uneventful.

The pathological study of the surgical specimens revealed vascular malformation with hamartomatous vascular ectasias in the mucosa and submucosa, with interstitial hemorrhage in the stomach; similar lesions in the duodenum were associated with calcification. The same pattern was observed in the small bowel and colon.

The patient remains without bleeding or anemia 1 year after the surgical procedure.

\section{DISCUSSION}

Blue rubber bleb nevus syndrome is characterized by cutaneous vascular malformations associated with gastrointestinal hemorrhage due to similar lesions in the gastrointestinal tract. The cutaneous malformations are bluish lesions that range from a few millimeters to several centimeters in diameter and occur preferentially in the trunk and upper extremities ${ }^{5}$. Although it is a rare syndrome, blue rubber bleb nevus syndrome must be considered in the differential diagnosis of anemia.

The intestinal lesions are more frequent in the small bowel, as occurred in the present case, although any anatomical site may be affected in the gastrointestinal tract ${ }^{5-7}$. In the colon, they are usually distal ${ }^{4}$. Intussusception, volvulus, and infarction may also occur $^{7-10}$. Lesions outside the gastrointestinal tract rarely bleed.
Diagnosis can be established by upper endoscopy and colonoscopy. Soft tissue masses not specific for hemangiomas can be revealed by CT scans. Selective arteriography and

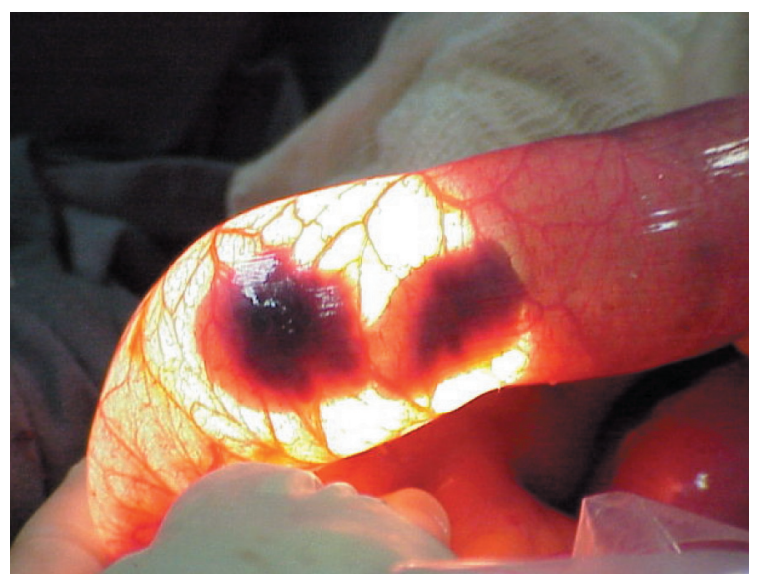

Figure 1 - Detection of lesions by enteroscopy (transillumination).
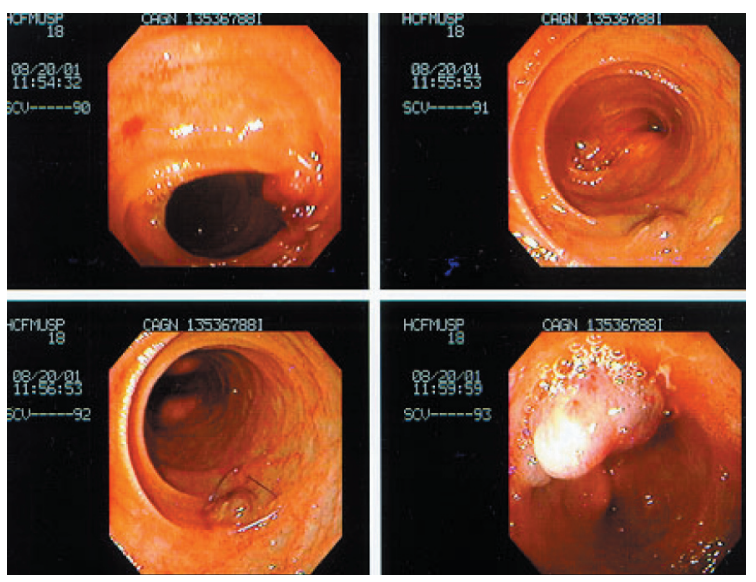

Figure 2 - Endoscopic view. Notice the purse string suture in the lower left slide.

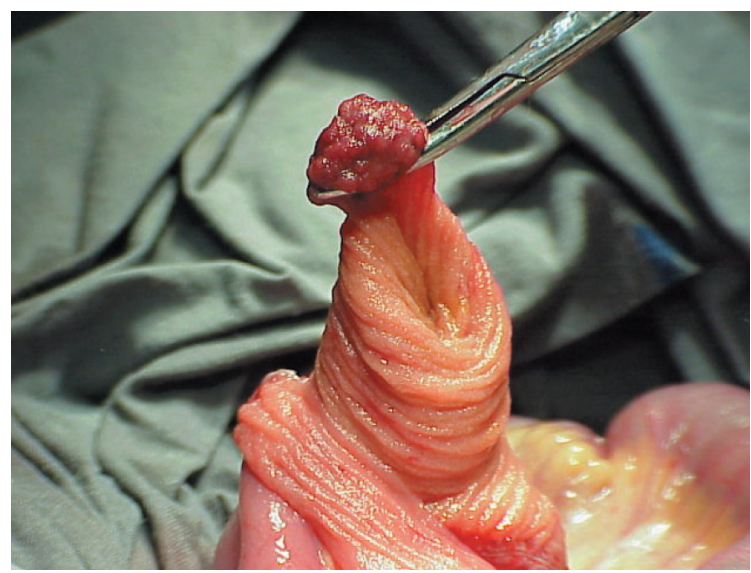

Figure 3 - Resection of lesion of the small bowel. 
scintillography are useful in cases of active bleeding.

In our case, the massive bleeding indicated surgical treatment. Enteroscopy performed during laparotomy allowed us to detect all lesions and to treat them by resection (larger ones) or by purse-string suture. We believe that all lesions must be treated in order to stop or prevent bleeding. In this case, the 1-year followup indicates that the procedure, although time-consuming, was worthwhile. We think that the detection of lesions by intraoperative endoscopy and treatment by purse-string suture is a desirable approach, since it avoids the risks of extensive intestinal resections as reported by Place $^{11}$.

Additional lesions will probably develop subsequently ${ }^{12}$. For a long period of time, the only therapeutic measure used in this case consisted of blood transfusions to replace blood loss when bleeding occurred; this strategy unfortunately led to infection by HIV virus. Patients with iron deficiency anemia should be investigated for the possibility of blue rubber bleb nevus syndrome. Endoscopy is the most reliable method for detecting these lesions and can act therapeutically through sclerosis ${ }^{13}$.

\section{RESUMO}

TEIXEIRA MG e col. - Síndrome do blue rubber bleb nevus: relato de caso. Rev. Hosp. Clín. Fac. Med. S. Paulo 58(2):109-112, 2003.

É descrito um caso da síndrome do blue rubber bleb nevus associada a infecção pelo vírus da imunodeficiência adquirida em conseqüência de múltiplas transfusões de sangue. Este caso demonstra que, embora rara, esta síndrome deva ser considerada no diag- nóstico diferencial da anemia crônica ou sangramento gastrointestinal. O melhor método diagnóstico é a endoscopia. A doente foi operada e submetida a esofagogastroduodenoscopia e endoscopia através de enterotomia com identificação de todas as lesões que foram tratadas, as maiores, por ressecção mínima e as demais por sutura em bolsa ao redor do nevo interessando toda a parede intestinal. A sutura em bolsa das lesões detectadas por enteroscopia demonstrou ser uma téc- nica efetiva no tratamento destas lesões, evitando assim ressecções intestinais extensas e parando o sangramento. $\mathrm{O}$ manuseio destes doentes demanda tratamento agressivo e deve ser iniciado precocemente para evitar riscos associados a transfusões sangüíneas como ocorreu neste caso.

DESCRITORES: Síndrome do blue rubber bleb nevus. Hemorragia. Cirurgia. 


\section{REFERENCES}

1. GENTRY R, DOCKERTY MB, CLAGETT OT - Vascular malformations and vascular tumours of the gastrointestinal tract. Int Abst Surg 1949; 88:281-323.

2. CAMILLERI M, CHADWICK VS, HODGSON JF - Vascular anomalies of the gastrointestinal tract. Hepato Gastroenterol 1984; 31:149-153.

3. BEAN WB - Blue rubber bleb nevi of the skin and gastrointestinal tract. In CHARLES C THOMAS - Vascular spiders and related lesions of the skin. Springfield, Illinois, 1958. p. 178-185.

4. ÖKSUZOGLU BC, OKSUZOGLU G, ULKEM C et al. - Blue rubber bled nevus syndrome Am J Gastroenterol 1996; 91: 780-782.

5. RODRIGUES D, BOURROUL MLM, FERRER APC et al. - Blue rubber bleb nevus syndrome. Rev Hosp Clin Fac Med S Paulo 2000; 55:29-34.

6. MACANNEL CA, HOENIG J, UMLAS J et al. - Orbital lesions in the blue rubber bleb syndrome. Ophtalmology 1996; 103:933936.

7. RADKE M, WALDSCHMIDT J, STOLPE HJ, et al. - Blue rubber bleb nevus syndrome with predominate urinary bladder hemangiomatosis. Eur J Pediatr Surg 1993; 3:313-316.
8. MOODLEY M, RANDIAL P - Blue rubber bleb nevus syndrome: Case report and review of the literature. Pediatrics 1993: 92; 160-162.

9. WONG SH, LAU WY - Blue rubber bleb nevus syndrome. Dis Colon Rectum 1982; 25:371-374.

10. BROWNE AF, KATZ S, MISER J, BOLES T - Blue rubber bleb nevi as a cause of intussusception. J Ped Surg 1983; 18:7-9.

11. PLACE RJ - Blue rubber bleb nevus syndrome: a case report with long-term follow-up. Mil Med 2001; 166:728-730.

12. SANDHU KS, COHEN H, RADIN R, et al. - Blue rubber bleb nevus syndrome presenting with recurrences. Dis Dis Sci 1987; 32:214-219.

13. GALLO SH, MCCLAVE AS - Blue rubber bleb nevus syndrome: gastrointestinal involvement and its endoscopic presentation. Gastrointest Endosc 1992; 38:72-76. 